\title{
Jakobshavn Glacier, West Greenland: 30 years of spaceborne observations
}

\author{
Hong-Gyoo Sohn' ${ }^{1}$, Kenneth C. Jezek ${ }^{1,2}$, and C.J. van der Veen ${ }^{1}$ \\ 'Byrd Polar Research Center and 'Department of Geological Sciences, The Ohio State University, \\ Columbus, $\mathrm{OH}$
}

\begin{abstract}
Early 1960's reconnaissance satellite images are compared to more recent image and map data in an interannual and seasonal study of West Central Greenland margin fluctuations. From 1962 to 1992 , ice sheet margins to the north and south of Jakobshavn Glacier retreated despite a decline in average summer temperatures. The retreat may be reversing along the southern flank of the ice stream where regional mass balance estimates are positive. From 1950 to 1996, the terminus of Jakobshavn Glacier seasonally fluctuated $\sim 2.5 \mathrm{~km}$ around its annual mean position. The total calving flux during the summer is more than six times that during winter. We identified that summer melting and the break-up of sea ice and icebergs in the fjord are important in controlling the rate of iceberg production. If correct, calving rates may be expected to increase should climate become warmer in the near future.
\end{abstract}

\section{Introduction}

Earth's ice cover is changing. Glaciers and ice caps located in middle and temperate latitudes are retreating [World Glacier Monitoring Service, 1994] whereas glaciers in Scandinavia are advancing [Haakensen, 1995]. The behavior of the great polar ice sheets is largely unknown, limiting our understanding of sea level rise and climate variability.

The simplest way to measure glacier change is to map and monitor glacier perimeters over time. This must be done on a regional scale because the change of an individual glacier need not be correlated with the regional trend [Sturm et al., 1991]. Airborne and spaceborne images provide high-resolution, glacier-mapping data over large areas. Until recently, airborne data were available only over a few locations and detailed spaceborne images were available only since the 1970's. However, a new source of much older spaceborne data is now accessible to the geoscience community. Early reconnaissance satellite images, gathered in the 1960's and released for scientific analysis in 1995, provide high quality images of much of the Earth, including Greenland and Antarctica [McDonald, 1995]. They establish accurate benchmarks for gauging glacier changes over the past 30 years.

\section{Data Sets}

Using a sequence of airborne and spaceborne data, we analyzed changes in the Greenland ice sheet margin from 1962 to 1992 . A 1962 reconnaissance satellite image (Corona) is our

Copyright 1998 by the American Geophysical Union.

Paper number 98GL01973.

0094-8534/98/98GL-01973\$05.00 starting point. A portion of the 1962 image (37.5 km x $37.5 \mathrm{~km})$ taken on May 17, 1962 (Figure 1(a)) shows the calving margin of Jakobshavn Glacier, one of the world's fastest moving glaciers reaching speeds up to $7 \mathrm{~km} /$ year near the calving front [Iken et al., 1993]. Figure 1 also includes subsequent, similar images acquired by aerial photography on July 10, 1985 (Figure 1(b)), by the SPOT (System Pour lObservation de la Terre) visible imaging satellite on May 30, 1988 (Figure 1(c)) and by the European Space Agency's SAR (Synthetic Aperture Radar) image on August 20, 1992 (Figure 1(d)). The dimensions of each image are $37.5 \mathrm{~km}$ by $37.5 \mathrm{~km}$. The original resolution of each image varies approximately from $140 \mathrm{~m}$ (Corona) to $10 \mathrm{~m}$ (aerial photograph).

We resampled the four images to a spatial resolution of $50 \mathrm{~m}$ and used nine tie points for coregistration. The final images were mapped on the same UTM (Universal Transverse Mercator) projection. The four images in Figure 1 clearly show surface features characteristic of a fast moving glacier embedded in the more sluggish main ice sheet (lower center and right). The width of Jakobshavn Glacier is $\sim 6 \mathrm{~km}$ and visible features can be traced $\sim 150 \mathrm{~km}$ inland. In the lower left of each image the iceberg-clogged fjord and the calving terminus are clearly discernible. Two types of margins are visible in Figure 1, namely grounded margins to the north and south of Jakobshavn Glacier, and the floating calving front. Both types are expected to behave differently under climate variations. Because the calving front is more dynamically active, the data set has been supplemented with the results of several earlier studies [Carbonnel and Bauer, 1968; Weidick, 1991; Fastook et al., 1995; Krabill et al., 1995], available topographic maps, and additional SAR observations. These data were coregistered to the image data using a polynomial rectification technique.

\section{Position of the Grounded Ice Sheet Margin}

We extracted grounded ice sheet margins by using a series of segmentation techniques [Sohn and Jezek, 1996]. The accuracy of the algorithm to delineate the ice sheet margin is less than $100 \mathrm{~m}$ in ground resolution. The ensemble of margin positions are shown in Figure 2, together with historical observations of ice margin extent compiled by Weidick (dashed lines) [Weidick, 1992].

Weidick [1991] showed that from 1950 to 1985 , ice margins near Jakobshavn Glacier retreated, while in areas $100 \mathrm{~km}$ to the north and $50 \mathrm{~km}$ to the south glaciers advanced. Our data support and extend this observation. Six locations along the margin to the north and south of Jakobshavn Glacier (Number 16 in Figure 2) were selected for detailed study. Distances between ice sheet margins and arbitrarily chosen reference points are shown in Figure 3 and indicate a retreat of $\sim 500 \mathrm{~m}$ to $1200 \mathrm{~m}$ between 1962 and 1992 . Estimated errors are about 


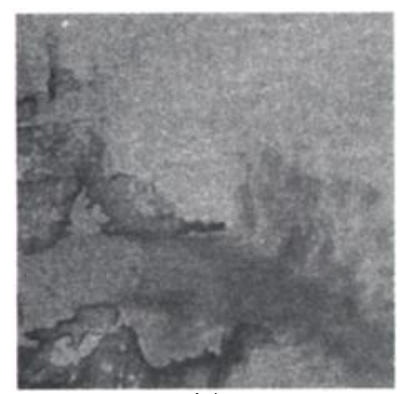

(a)

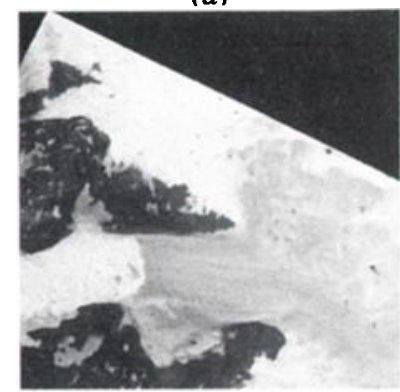

(c)

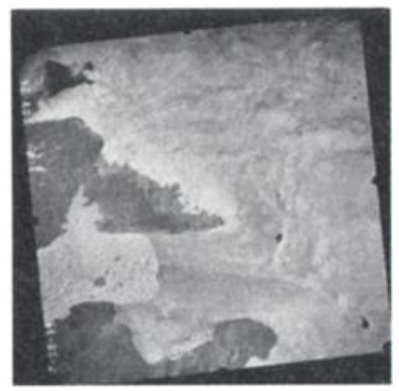

(b)

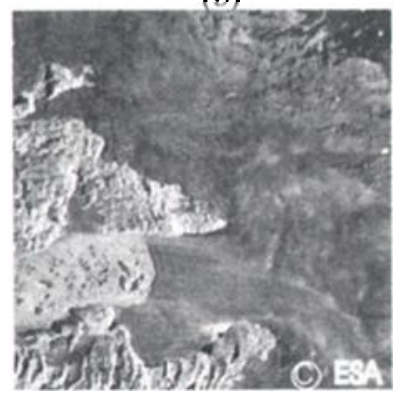

(d)

Figure 1. Jakobshavn Glacier margins (a) May 17, 1962 Corona image (b) July 10, 1985 Aerial photograph (c) May 30, 1988 SPOT image (d) August 20, SAR image.

$\pm 140 \mathrm{~m}$ based on $100 \mathrm{~m}$ uncertainty in the ice sheet margin detection algorithm and $100 \mathrm{~m}$ from the geocoding procedure. Localized areas of retreat are especially evident around nunataks (rocky islands protruding through the glacier) located in the northern part of the study area. South of Jakobshavn Glacier we find weak evidence of glacier readvance (area 1 and area 2 in Figure 3). The magnitudes of the ice margin displacements (up to $1.2 \mathrm{~km}$ ) north of the ice stream are consistent with other observations and model results [Reeh, 1983; Weidick, 1991].

The general pattern of retreat over the past 30 years may be ending. Temperature records at Egedesminde, located about 90

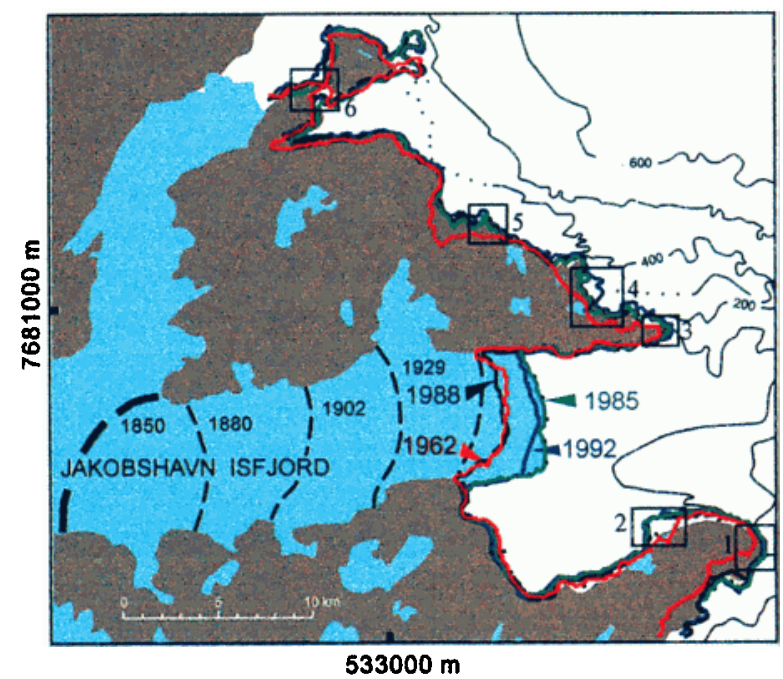

Figure 2. The ensemble of ice sheet margins. The detected ice sheet margins from four different remote sensing data sets (heavy solid lines) are combined with Weidick's results shown as dashed black lines [Weidick, 1992]. Blue represents ocean, brown represents exposed rock and white represents the present ice sheet.

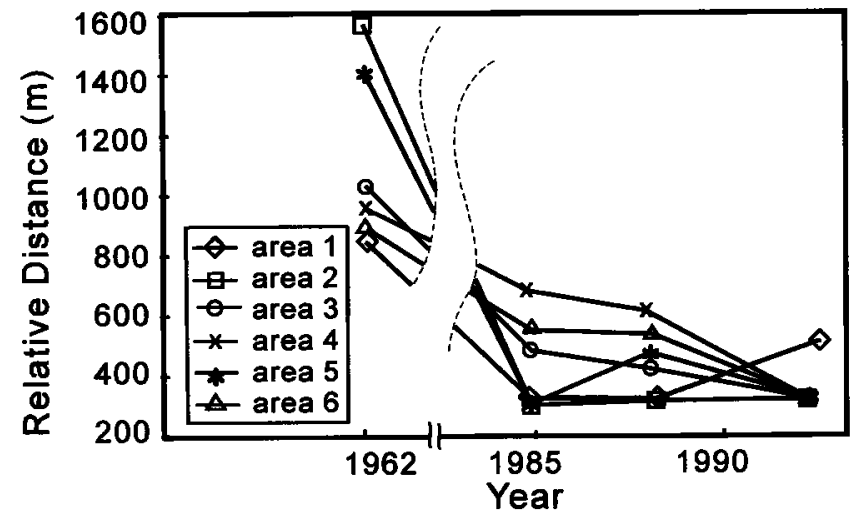

Figure 3. Ice sheet margin patterns at six locations shown in Figure 2.

km southwest of the Jakobshavn calving front, show that average summer temperatures (June August) have declined during the past 30 years. Moreover, several studies suggest that the interior ice sheet in this region is thickening by about $10 \mathrm{~cm}$ per year [Davis, 1995; Krabill et al., 1995]. As the margin retreats and interior ice builds up, the ice sheet will oversteepen. Eventually, the weight of the glacier will cause the margin to creep forward. We believe this process may already be occurring on the southern flank of the ice stream.

\section{Fluctuations of The Calving Front}

Over the past century, the calving front of Jakobshavn Glacier has retreated $\sim 25 \mathrm{~km}$ from the mouth of the fjord to near its head [Weidick, 1992]. This general trend of retreat appears to have halted in recent years and currently, periodic seasonal

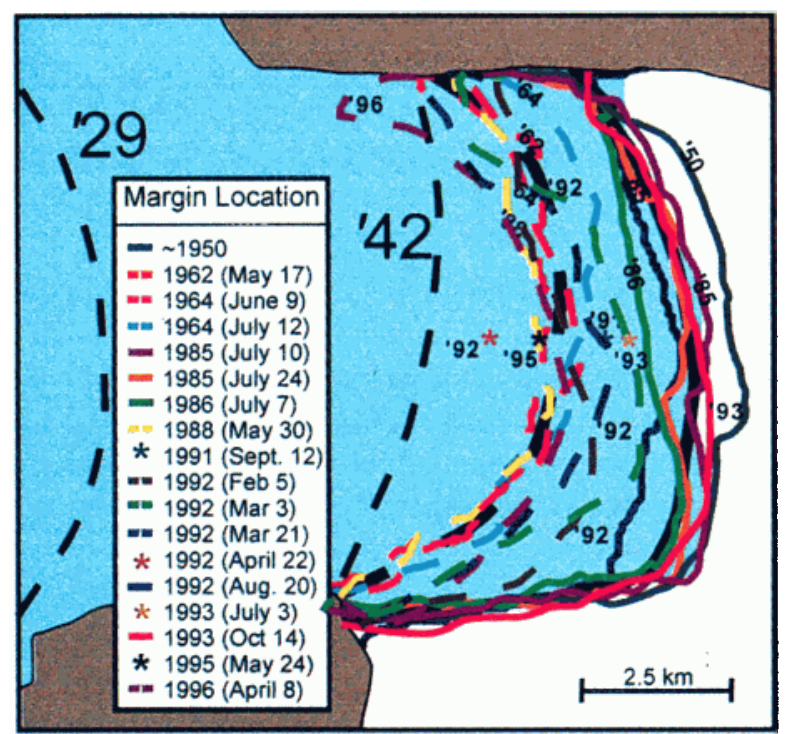

Figure 4. Calving front fluctuations. The observation of $\sim 1950$ is based on published topographic maps $(1: 250,000$ series, Geodætisk Institut, Copenhagen). The calving front of 1964 is from Carbonnell and Bauer's observation [Carbonnel et al., 1968]. The results of 1985 and 1986 are from Fastook and others [Fastook et al., 1995]. The point locations of calving front of $1991,1992,1993$, and 1995 were measured by laser altimetry [Thomas et al., 1995]. All the other results are from ERS-1 SAR imagery. 
advance and retreat characterize the position of the calving front. To describe seasonal fluctuations of the calving front, we have combined our results with additional measurements of the ice margin position (Figure 4). Since 1950, the calving margin has seasonally fluctuated $2.5 \mathrm{~km}$ around a stable, mean terminus position. Spring time calving front positions are usually $2 \mathrm{~km}$ to the West of the summer time calving margins. This demonstrates that retreat rates must be estimated from margin positions mapped at roughly the same time of year to separate the signals of systematic retreat and seasonal fluctuations.

Using our data we can estimate calving rates during the summer months and compare these values to the winter averages. We observe that, on average, the calving front advances to its maximum forward position by late winter or early spring ( May, Julian day 121 , Thick black dashed line in Figure 4) and retreats to a retracted position by the end of summer ( August, Julian day 243 , thick black solid line in Figure 4). The area bounded by the positions corresponds to the area calved during the summer (May to August) and is $20 \mathrm{~km}^{2} \pm$ $2 \mathrm{~km}^{2}$. Based on the elevation of the ice margin [Thomas et al., 1995] and on ice sounding radar measurements of iceberg thickness [Chuah et al., 1996], we estimate the ice thickness at the calving front to be $800 \pm 50 \mathrm{~m}$, similar to the estimate of Pelto and others [1989]. This yields a calving volume flux of 1.6 $\times 10^{10} \pm 0.1 \times 10^{10} \mathrm{~m}^{3}$ during the four month period. This flux is in addition to that required to evacuate ice advected from the interior to the terminus. The annual flux of ice into the terminal region is estimated to be between 3.4 and $4 \times 10^{10} \mathrm{~m}^{3}$ /year [Pelto et al., 1989]. There is little or no seasonal fluctuation in velocity [Echelmeyer and Harrison, 1990], so this value may be considered constant throughout the year. Thus, the total calving flux over the four-months summer period is $1 / 3$ of the annual ice flux into the terminus region plus the volume flux of the seasonal ice tongue, giving $2.9 \times 10^{10} \mathrm{~m}^{3}$. Similarly, during the remaining 8 month period, when the terminal tongue reforms, the estimated volume flux is $1.1 \times 10^{10} \mathrm{~m}^{3}(2 / 3$ of the annual discharge from upglacier minus the volume of the tongue). Dividing these fluxes by the length of summer ( 4 months) and winter (8 months) shows that during the summer months (May August) the estimated calving rate on Jakobshavn is about 6 times as large as the winter calving rate. That is, more than half of the annual iceberg production occurs during the summer.

We examined the seasonal variation in calving rate by plotting all of our data by Julian day. We assume that inter annual variations are small. The average, central, terminus position as a function of Julian Day is shown in the first panel of Figure 5 and indicates a progressive retreat of the calving front during the summer and advance during the winter. The heavy line in the first panel of Figure 5 represents the best fit to the data. Because the ice velocity is constant throughout the year, the calving rate can be estimated differentiating the terminus position with respect to time. This yields the calving rate shown in the second panel (assuming an ice velocity of $7 \mathrm{~km} / \mathrm{year}$, indicated by the horizontal line in the second panel). The results show that the calving rate starts to increase rapidly around the end of April and maintains a maximum from about mid-June to the middle of July. In early August, the calving rate starts to decrease and this decrease continues throughout the winter.

There are several hypothesis that may explain this curve. Perhaps surface crevasses become water-filled during the summer, allowing crevasses to penetrate the entire ice thickness [Weertman, 1973; van der Veen, 1997], or downward percolation of meltwater may weaken the ice in the terminal

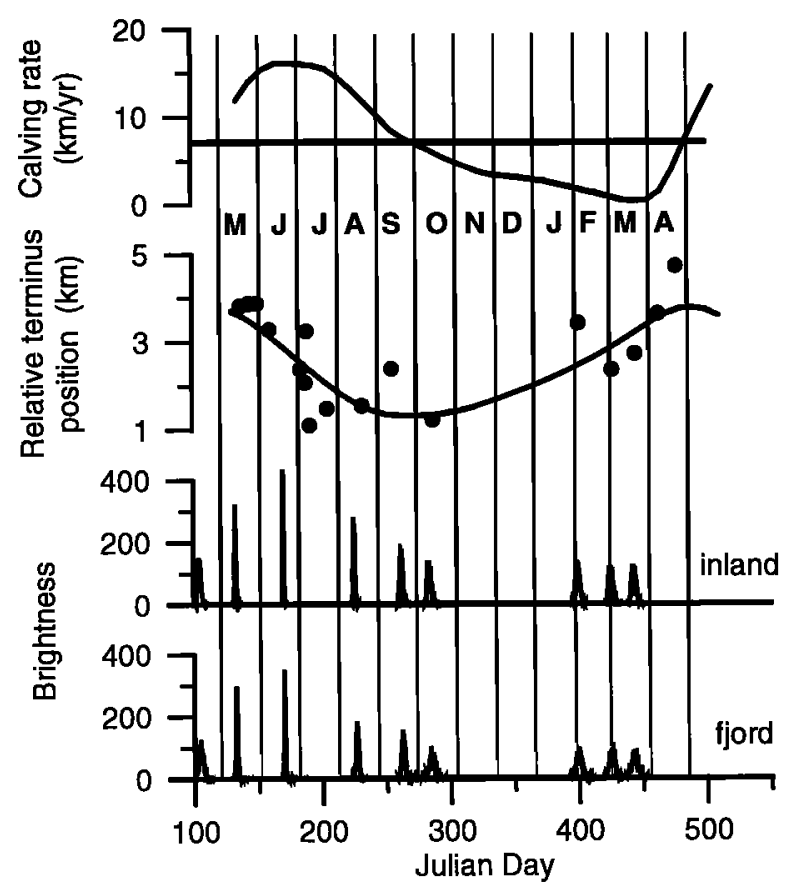

Figure 5. Terminus position of Jakobshavn Glacier relative to the 1942 position, as a function of Julian Day, for the period 1962-1996. The solid line in the first panel represents the best fit curve to the data points. The curve in the second panel represents calving rate derived through the derivatives of the curve in panel 1 . The third and fourth panels represent the histograms of brightness for inland glacier and fjord areas, respectively. The histograms are normalized against the range of the digital numbers.

region [Liu and Miller, 1979] as suggested by Vaugh and Doake [Vaughan and Doake, 1996] for ice shelves in the Antarctic Peninsula. Another possibility is that confining sea ice icebergs in the fjord and maintain the integrity of the floating tongue; melting of the sea ice cover may result in dispersal of the calving tongue as appears to be the case in Northern Greenland [Higgins, 1990].

To deduce the controlling mechanism from our observations, a series of SAR imagery was studied. First, we selected a calibration site (6x6 km in size) over rocky terrain to use as a reference for estimating relative changes in radar brightness (digital number). Next we selected two test areas $4 \times 4 \mathrm{~km}$ in size. One covered part of the glacier and the other covered part of the fjord area. Both were within $10 \mathrm{~km}$ of calving front. Histograms of brightness for each selected area were created and the patterns examined (third and fourth panel of Figure 5). If surface melting occurs, backscattering from the surface is very low and the shape of the histogram becomes very narrow and peaked. As water starts to freeze, backscattering from the surface gradually increases and the histogram becomes wider. Our results during the winter months suggest a melt threshold of about 100 to 120 (frequency of occurrence of a digital number value). Thus we determined that surface melting starts Julian Day 109 (middle of April) both for the inland and fjord areas. From then on, the calving rate increases rapidly, as shown in Figure 5. Surface melting reaches its peak around Julian Day 170 (end of June) at which time the calving rate reaches its maximum. Inland, surface water starts to freeze around Julian Day 260 (middle of September). Fjord sea water, on the other 
hand, freezes up around Julian Day 280 (early October). From then on, the calving rate continuously decreases throughout the winter.

Our data show that there is a strong correlation between ice sheet surface melting, the melting of fjord ice and the rapid increase of calving rate during summer. But the available data are inconclusive as to which of the two processes is most important. On one hand, the presence of abundant surface meltwater enhances the ability of crevasses to penetrate the ice thickness. On the other hand, the break-up of confining fjord ice reduces the restraining force acting on the calving front. Together, theses two processes probably cause the observed increase in calving rate during the summer. If surface meltwater were the solely dominant control on calving rate, one would expect a sudden decrease in calving rate at the end of summer as the surface meltwater drains or refreezes. Instead, Figure 5 shows that the calving rate starts to decrease gradually at the end of summer and this decrease continues throughout the winter. This implies that the main factor controlling the calving rate during the winter is the gradual consolidation of sea ice and icebergs in the fjord, which increases the force acting on the terminus, thus impeding the calving process.

\section{Conclusions}

Grounded margins to the north and south of Jakobshavn Glacier generally retreated over the last 30 years. South of Jakobshavn, our data indicate a weak glacier readvance. We found that during the last 40 years the calving front of Jakobshavn fluctuates $\sim 2.5 \mathrm{~km}$ around a stable, mean terminus position. By comparing the front position in spring and late summer, we estimate that the rate of iceberg production during the summer is almost six times that during the winter. Surface melting and the break up of ice in the fjord are strongly correlated with the summer increase in iceberg production. This suggests that enhanced surface melting may directly lead to increased calving, while gradual formation of sea ice during the winter results in a progressive decrease in iceberg production. Consequently, a climate warming may lead to a prolonged season of high calving rates, which would increase the annual calving flux.

Acknowledgments. This work was supported by NASA's polar oceans and ice sheets program. SAR data were provided by the European Space Agency.

\section{References}

Carbonnel, M. and A. Bauer, 1968, Exploitation des couvertures photographiques aécriennes répétrés du front des glaciers vêlant dans Disko Bugt et Umanak Fjord, juin-juillet 1964, Medd. Grønl., 173 (5).

Chuah, T.S., S.P.Gogineni, C. Allen, and B. Wohletz, 1996, Radar Thickness Measurements over the Northern Part of the Greenland Ice Sheet, RSL Technical Report 10470-3.
Davis, C.H., 1995, Growth of the Greenland Ice Sheet: A Performance Assessment of Altimeter Retracking Algorithms, IEEE Transactions on Geoscience and Remote Sensing, Vol. 33, No. 5, pp. 1108-1116.

Echelmeyer, K. and W.D. Harrison, 1990, Jakobshavns Isbra, West Greenland: Seasonal Variations in Velocity - or Lack Thereof, Journal of Glaciology, Vol. 36, No. 122, pp. 82-88.

Fastook, J.L., H.H. Brecher, T.J. Hughes, 1995, Derived bedrock elevations, strain rates and stresses from measured surface elevations and velocities: Jakobshavns Isbræ, Greenland, Journal of Glaciology, 41 (137), pp. 161-173.

Haakensen, N., Ed., 1995, Glasiologiske undersøkelser i Norge 1992 og 1993, NVE publikasjon 8.

Higgins, A.K., 1990, North Greenland glacier velocities and calf ice production, Polarforschung, 60(1), pp. 1-23.

Iken, A., K. Echelmeyer, W. Harrison, and M. Funk, 1993, Mechanisms of fast flow in Jakobshavn Isbre, West Greenland :Part I, Journal of Glaciology, Vol. 39, No. 131, pp. 15-25.

Krabill, W., R. Thomas, K. Jezek, K. Kuivinen, and S. Manizade, 1995, Greenland ice sheet thickness changes measured by laser altimeter, Geophysical Research Letters, Vol. 22, No. 17, pp. 2341-2344.

Liu, H.W. and K.J. Miller, 1979, Fracture toughness of fresh-water ice, Journal of Glaciology, Vol. 22, No. 86, pp. 135-143.

McDonald, R.A., 1995, Opening the Cold War Sky to the Public: Declassifying Satellite Reconnaissance Imagery, Photogrammetric Engineering and Remote Sensing, Vol. 61, No. 4, pp. 380-390.

Pelto, M.S., T.J Hughes, and H.H. Brecher, 1989, Equilibrium State of Jakobshavns Isbræ, West Greenland, Annals of Glaciology, No. 12, pp. 127-131.Reeh, N., 1983, Ikke-stationæ beregingsmodel for Indlandsisens randzone, Grønlands geol. Unders. Gletscher-hydrol. Meddr, 83/7, 81 pp.

Reeh, N., 1983, Ikke-stationæe beregingsmodel for Indlandsisens randzone, Grønlands geol. Unders. Gletscher-hydrol. Meddr, 83/7, 81 pp.

Sohn, H.G. and K.C. Jezek, 1996, Ice Sheet Margin Detection Using ERS-1 Synthetic Aperture Radar, IGARSS 96, Lincoln, pp. 148-151.

Sturm, M., D.K. Hall, C.S. Benson, and W.O. Field, 1991, Non-climatic control of glacier-terminus fluctuations in the Wrangell and Chugach Mountains, Alaska, U.S.A., Journal of Glaciology, Vol. 37, No. 127, pp. 348-356.

Thomas, R., W. Krabill, E. Frederick, and K. Jezek, 1995, Thickening of Jakobshavn Isbra, West Greenland, measured by airborne laser altimetry, Annals of Glaciology, 21, pp. 259-262.

van der Veen, C.J., 1997, Fracture mechanics approach to penetration of surface crevasses on glaciers, Cold Regions Science and Technology, in press.

Vaughan, D.G. and C.S.M. Doake, 1996, Recent atmospheric warming and retreat of ice shelves on the Antarctic Peninsula, Nature, Vol. 379, No. 25, pp. 328-331.

Weertman, J., 1973, Can a water-filled crevasse reach the bottom surface of a glacier?, IASH Publ. 95, pp.139-145.

Weidick, A., 1991, Present-day expansion of the southern part of the Inland Ice, Grønlands geol. Unders., 152, pp. 73-79. Rapp. Grønlands geol. Unders., 152, pp. 73-79.

Weidick, A., 1992, Jakobshavn Isbræ area during the climatic optimum, Rapp. Grønlands geol. Unders., 155, pp. 67-72. 3.

World Glacier Monitoring Service, 1994, Glacier Mass Balance Bulletin

Hong-Gyoo Sohn, Kenneth C. Jezek, and C.J. van der Veen, Byrd Polar Research Center, The Ohio State University, 1090 Carmack Road, Columbus, OH, 43210. (e-mail: sohn@iceberg.mps.ohiostate.edu; jezek@iceberg.mps.ohio-state.edu; vanderveen.1@osu.edu)

(Received January 28, 1998; accepted June 5, 1998) 